\title{
グローバル原子カ安全・セキュリティ・エージェント養成
}

\section{(1) 全体概要と成果}

東京工業大学 齊藤 正樹

\begin{abstract}
東京工業大学では，全寮制の「世界原子力安全・セキュリティ道場」を基盤として，演習・実 習を含むコースワークや国内外インターンシップ等を重視した修士・博士一貫型の学位プログ ラムによって,「人類の生存基盤を脅かす核拡散, 核テロ, 大規模な原子力災害や緊急被ばく問 題等のグローバルな原子力危機」の分野において, 高い国際交涉能力を有し, 国内外の原子力関 連の産官学界で国際的リーダーとして活躍する人材「グローバル原子力安全・セキュリティ・ エージェント」を養成している。本稿では本学位プログラムの概要と成果について述べる。
\end{abstract}

KEYWORDS: Doctoral program, Global leader, Nuclear safety, Nuclear security, Nuclear safeguards, Nuclear dojo, Course work, Training, Exercises, Nuclear 3s symposium and seminar

\section{I .はじめに}

本学位プログラムは，文部科学省「博士課程教育リー ディングプログラム」六のオンリーワン型として平成 23 年 11 月末に採択された修士・博士一貫型である。本学 位プログラムの目的は,「人類の生存基盤を脅かす核拡 散, 核テロ, 大規模な原子力災害や緊急被ばく問題等の グローバルな原子力危機」の分野において，高い国際交 渉能力を有し, 国内外の原子力関連の産官学界で国際的 リーダーとして活躍する人材「グローバル原子力安全・ セキュリティ・エージェント」を養成することである。

本学位プログラムでは，深い専門性はもとより，幅広 い社会性や国際性を備え, さらに豊かな人間性を養い, 時代の流れを俯瞰しながら「高い志を持って，人々のた めに，社会のために，世界のために，貢献する原子力 リーダー」を育成することを教育目標としている。

本学位プログラムでは, 平成 24 年 10 月から学生を受 け入れ, 平成 29 年 3 月に最初の修了生 3 名を輩出し, 現 在は 17 名が所属している。

本稿では, 本学位プログラムの特徴を中心とした全体 概要および成果について述べ，国内外インターンシップ と今後の展望の詳細は引き続く別稿で述べられる。

\section{II. 学位プログラムの特徵}

1. 世界原子力安全・セキュリティ道場

全寮制の「世界原子力安全・セキュリテイ道場」を，お

Global Human Resource Development Program for Nuclear Safety and Security(1); Overview and Achievements: Masaki Saito.

(2017 年 10 月 30 日 受理)
台場にある日本学生支援機構「東京国際交流館」の一部を 借り上げて平成 24 年 10 月に開設した。

東京工業大学・原子核工学専攻 (平成 28 年度からは原 子核工学コース) 修士課程に入学し, 3 力月間のラボ. ローテーションを経て研究室に所属した 1 年生で本学位 プログラム所属を希望する者に対して 1 次選抜試験を行 い, 合格者を道場に入門させた。道場には教員も住み込 み, また, 後述の道場自主ゼミには他のプログラム担当 教員が輪番制で参加した。

道場では, 原則英語による「道場自主ゼミ」を毎週夜 (20:00〜22:00)に開催し, 教員はファシリテーターの役 割を適宜演じた。自主ゼミのテーマは原子力以外の答え のない時事問題を中心に, 例えば, シリアの難民問題や 2016 年の米国大統領選挙等を学生が選んだ。また, 道場 学生は東京国際交流館のレジデント・アシスタントとし て, 同館に入居している一般の留学生や海外からの研究 者およびその家族の生活の支援をする役目を果たす。ま た, 他のレジデント・アシスタントと一緒に種々のイベ ントを企画・実施する。さらに, 所属学生独自で, 教員 も協力し, 原子力や放射線に関するサイエンス・カフェ を毎年開催している。自主ゼミやこれらの活動によっ て, 所属学生のディベート能力, 社会コミュニケーショ ン能力の向上や国際力の強化を行っている。

\section{2. 充実したコースワーク}

本学位プログラムではグローバル原子力リーダーの育 成を目的としているため, 所属学生は, 通常課程の「原子 力基礎 - 専門科目群」(16 単位以上)に加えて, 本学位プ ログラム独自の演習・実習を含む授業科目 (26 単位以上) を履修することが修了要件として求められている。以下 
に本学位プログラム独自の授業科目について簡単に述べ る。

\section{(1) 原子力道場科目群 (6 単位)}

原子力道場第一〜第六の 6 科目 (各 1 単位) で, 修士 1 年生から博士 3 年生までに順次履修する。各科目の主な 内容は,

第一：原子力・放射線最先端研究

第二：種々のグローバルセキュリティ課題

第三：種々のリスク，リスク評価，リスク管理

第四：緊急時対応，危機管理，リスク管理

第五：原子力利用のあり方

第六：グローバルリーダー論

である。第六は博士 3 年後学期に履修し, 授業の中で各 学生は各自のグローバルリーダー像を発表し，履修生全 員での議論を行う。

(2) 原子力安全・セキュリティ科目群 (8 単位)

演習・実習を含む下記の 4 科目 (各 2 単位)である。

○環境放射線計測フィールドワーク：福島地域での フィールドワーク実習を含む。

○原子炉過酷事故シミュレーション：電力会社のシミュ レーターを用いた実習を含む。

○放射性物質環境動態：日本原子力研究開発機構が開発 した計算コード WSPEEDI-II を用いた実習を含む。

○核セキュリテイ実習 : 研究機関の施設を用いた実習を 含む。

(3) 社会・コミュニケーション科目群 (3 単位)

本科目群は下記の 3 科目から構成される。

○リスクコミュニケーション I およびII (各 1 単位)

○原子核工学ボランティア活動第一(前学期)あるいは第 二(後学期) (各 1 単位)：実習としては福島地域等での ボランティア活動を含む。

(4) 高度国際教養科目群 (9 単位)

本科目群は下記の 9 科目 (各 1 単位) から構成される。

○グローバル世界における英語

原子力国際関係論

○国際政治経済とエネルギー戦略

○フンス語とフランス文化

○国際法の基礎と外交

$\bigcirc$ 原子力研究・開発・利用の歴史

哲学基礎

○文化・文明論基礎

○芸術と人間

\section{3. 国内外インターンシップ}

所属学生は博士課程において国内インターンシップ (3〜6 月月) と国際インターンシップ（6 カ月～1 年)を実 施することが義務付けられており，このため，必修の授 業科目として「グローバル原子力インターンシップ (2 単 位)」と「グローバル原子力国際インターンシップ第一,
第二 (各 2 単位)」が用意されている。この国内外イン ターンシップについては別稿で詳しく述べられるので本 稿でのこれ以上の記述は割愛するが，国際インターン シップを通して国際交渉力の強化等が行われている。

\section{4. 国際シンポジウム・セミナー}

所属学生の原子力 $3 \mathrm{~S}$ (Safety, Security, Safeguards)に 関する知識を広め深化させるため, また，所属学生の国 際化とリーダー教育を兼ねて，原子力 $3 \mathrm{~S}$ に関する国際 シンポジウム・セミナーを毎年度，合計 7 回開催した。

国際シンポジウム・セミナーは通常 2 週間にわたり, 最初の 2〜3 日間は一般公開のシンポジウムとし，続く 週末を含む 3 4 日間は受講生 (所属学生, 国内外から招 聘した 20〜30 名の学生・若手研究者・技術者・行政官 等)による国内研修(東京電力福島第一原子力発電所を含 む国内の原子力施設見学や広島・長崎の原爆関連施設見 学からなり，東北地方の原子力施設見学の場合は，福島 地域での放射線計測フィールドワークも行った。），最後 の 4 日間程度は非公開の受講生セミナーとした。

受講生をあらかじめ各 5〜6 名のグループに分け，各 グループのリーダーには所属学生を当てた。各グループ はシンポジウム・セミナーのみならず，夕食や夜の活動 等を団体行動で行うようにさせた。このことによって, グループリーダーとなった所属学生およびリーダーをサ ポートする所属学生の国際力とリーダーシップ等の強化 が意識的に行われた。

シンポジウムとセミナーには国際機関や国内外の大学 および研究機関等の第一級の専門家を講師として招聘し た。セミナーでは, 受講生が招聘講師等による講演を数 件聴講し, グループ内で講演内容についてディスカッ ションを行い, グループとしての質問事項等を纏めた後 に，講師との質疑応答を行った。

最終日には，あらかじめ与えられたテーマに対して， 各グループで縓めた内容を発表させた。発表内容の縓め や発表資料の作成は主に夜の活動として行われた。

\section{5. 国内外研修}

国外研修は各 1 2 週間で毎年度数回，これまで合計 12 回行った。訪問国は米国，フランス，オーストリア， スイス，スウェーデン，リトアニア，ロシア，マレーシ ア，韓国等である。国外研修では国際機関等訪問 (IAEA，CTBTO，世界銀行，日本大使館，等), 原子力 施設見学, 訪問国の大学 (UCバークレー, テキサス A\&M, KAIST, ウィーン工科大学, カウナス工科大学, 等)の原子力専攻学生とのグループ・ディスカッション や研究発表会を行った。グループ・ディスカッションの テーマは所属学生が相手大学の学生と予め相談して決め た。

国内研修は数日〜1 週間で, 広島・長崎の原爆関連施 
設見学,「もんじゅ」や幌延の深地層研究施設等の原子力 施設見学等からなり, 毎年度数回, これまで合計 6 回 行った。

原爆の捉え方は日本と米国では大きく異なる。そのた め, 米国研修前には, 「広島平和記念資料館」㧍よび「長崎 原爆資料館」を訪問し，米国ラスベガスの「National Atomic Testing Museum」の展示の仕方と比較し, 同じ 歴史的出来事でも国によって評価が違うことを所属生に 学ばせ, 国際力の強化を行っている。

\section{6. 道場講話}

これまで 30 回開催した道場講話の講師として, IAEA, 世界原子力大学, フランス原子力庁, UC バーク レー, 在日フランス大使館, 資源エネルギー庁, 日本原 子力研究開発機構, 国立病院機構災害医療センター, 日 本原燃株式会社, 原子力環境整備促進・資金管理セン ター, テレビ朝日, 国際石油開発帝石, 笹川平和財団, 日立製作所, 東京電力, 原燃輸送株式会社等の各界の リーダー等 30 名(海外講師 11 名, 国内講師 19 名)を招 聘した。講演終了後には, 就職やキャリアパス等につい て, 講師と所属学生との意見交換の場を設けた。

\section{7. 独自の博士論文審査}

博士論文審査に抢いては，通常課程の審査員 5 名とは 別に, 学外審查員として国外 (2 名), 国内(1名)の著名な 専門家による「初期審査」「「中間審査」および「最終審査」 を受ける。

初期審査は博士課程進学後のなるべく早い時期に行 い, 博士論文研究の方向性が妥当か否かを審査し, 助言 を指導教員経由で学生に伝える。中間審査は博士 2 年の 中頃に博士論文研究の進捗について, 最終審査は博士 3 年の中頃に研究成果等について行い，助言を指導教員経 由で学生に伝える。助言は博士論文研究㧍よび論文執筆 にフィードバックさせることになる。

これらの審査では, 当該学生は英語による資料を用い て英語で発表・質疑応答を行う。

\section{III. 学位プログラムの成果}

\section{1. 教育体制の構築2)}

\section{(1) 学内規則等の整備}

本学位プログラムを実施するために, 東京工業大学の 組織運営規則を改訂し, 部局としての「グローバル原子 力安全・セキュリティ・エージェント教育院」を設置し, また, 大学院学則を改定して「グローバル原子力安全・セ キュリティ・エージェント教育課程」を設置した。そし て，教育院の規則と教育課程の規程を制定した。

規則には, 教育院長, 道場主, メンター, プログラム 担当者等を教育院に置くことが明記され，また，運営委 員会, 企画委員会, 実施委員会, 自己点検評価委員会,
外部評価委員会の設置と各委員会の運営が明記された。 規程には, 所属の時期, 所属学生の選考, 寄宿舎(道 場), 教育課程修了の要件等が明記された。

（2）世界原子力安全・セキュリティ道場の整備

東京工業大学には本学位プログラムの全寮制道場とし て利用できる寮がないので，まずは，民間アパートや社 員寮等を探した。道場には自主ゼミのための 20 名程度 入れる部屋が必要であるが, 民間アパートには大部屋は 皆無であった。また, 社員寮等についても道場として利 用できる物件は皆無であった。

お台場にある日本学生支援機構「東京国際交流館」の利 用可能性の情報を入手した。日本人学生としては入居で きないが，レジデント・アシスタントとしては入居でき る可能性がある。館長に本学位プログラムについて説明 したところ, 館長の特別な計らいでレジデント・アシス タントとしての入居が許可された。また，プログラム コーデイネーターと道場主の入居も許可された。

交流館の共用スペースで自主ゼミを行えるが，共用ス ペースの定期利用予約はできない。そこで，プログラム コーデイネーターを家族部屋 $\left(100 \mathrm{~m}^{2}\right)$ に入居させて貫い, 食堂と居間を合わせて自主ゼミのスペースに当てた。こ の家族部屋に道場用の什器, $\mathrm{OA}$ 機器, 書籍等を持ち込 むことで道場の整備が行われた。その結果, 子供部屋が プログラムコーディネーターの寝室となってしまった。

(3)独自授業科目の開発と実施

前述の本学位プログラム独自の演習・実習を含む授業 科目 (26 単位以上) の全てを一挙に開講するのは現実的 ではない。そこで，まず，各科目の効果的・効率的な履 修順番を考慮して，標準履修スケジュールを作成した。 そして, 所属学生の学年進行に沿って平成 24 年度の後 学期から順次開講し, 平成 28 年度後学期で完了させる こととした。

授業開発も開講スケジュールに基づいて行うこととし た。開発する授業科目関連分野に専門性を有する特任教 員を採用し，プログラム担当者と協同で授業開発を行っ た。非常勤講師による授業実施が必要な高度国際教養科 目等の一部については，授業内容の骨子を作成し，骨子 内容に沿った非常勤講師の選定を行った。選定に当たっ ては, 他大学の教員のみならず, 官庁, 在日大使館, 研 究機関，民間企業等の職員も対象とした。

東京工業大学の授業時間割は月～金曜日の $1 \cdot 2$ 時限 (09:00 開始) 7 · 8 時限 (16:35 終了) であり（水曜日は原 則午前中のみ。), 原子核工学専攻 (コース)の通常授業科 目で殆ど全ての杂が埋まっている。そこで, 独自授業科 目には水曜日午後を含む僅かな空き枠と 9 時限以降を利 用するしかない。学生に過度な負担を科さないよう 9 時 限以降は原則禁止されているので，特別許可を鿓って 9 時限以降にも独自科目を開講した。このため, 道場自主 ゼミの開始時刻を 20:00 としている。 


\section{2. 修了生の輩出}

本学位プログラムの修了要件は, 原子核工学専攻 (コース)の修了要件に加えて, 次の $(1) \sim(6)$ に対する学 生の取り組みと成果を総合的に判定する書面と面接によ る審査に合格することとした。(1) 全寮制の道場で切硡 环磨すること。(2) 修士課程修了時に 2 次選抜試験を受 けて合格すること。(3)独自の演習・実習を含む授業科 目を履修すること。(4) 国内外インターンシップを行う こと。(5) 博士論文審査において, 本学位プログラム独 自の初期審査, 中間審査, 最終審査に合格すること。(6) 原子力 $3 \mathrm{~S}$ に関する国際シンポジウム・セミナー, 海外 研修, 国内研修, 道場講話, サイエンス・カフェ等に参 加して各自の役割を果たすこと。

修了要件から分かるように, 所属学生はコースワー ク, 学位論文研究, 国内外インターンシップ, 種々のイ ベントでとにかく忙しい。コースワークは, 修了迄に 80 単位程度の取得となる。国内外のインターンシップ期間 の合計が 9 カ月〜 1.5 年であることを考えると，すさま じい単位数であり, タフでないとやっていけない。

このような厳しい修了要件であったが, 平成 29 年 3 月に最初の修了生 3 名が産業界と研究機関に巣立って いった。現在は修士 1 年生〜博士 3 年生の 17 名が所属 している。本学位プログラム修了者が将来, 我が国のみ ならず世界の原子力界でグローバルリーダーとして活躍 し貢献することが大いに期待される。

\section{3. 東工大・教育改革への波及}

東京工業大学は平成 28 年 4 月に教育改革を断行した。 改革では教育組織と教育体系を抜本的に見直し ${ }^{3)}$,「卓越 した専門性に加えてリーダーシップを備えた理工系人材 を育成し，より良い世界を創る。」という理念に基づき， 学生の主体的な学びを後押しする教育を開始している。 こうした教育改革の理念は, 本学位プログラムを含む東 京工業大学で実施されてきた 4 つの博士課程教育リー ディングプログラムの実績と経験に基づくものである。

新しい教育体系において, 学士課程から博士課程まで にわたる「教養コア学修」がリベラルアーツ教育の 1 つと して実施されている。この科目群は, 学生が自身の専門 性を背景に, 他の学生の能力を最大限に活かしながら目 標に向かってチームを導くリーダーシップを身に付ける ことを目指しており，博士課程教育リーディングプログ
ラムの理念が全学に共有され，教育体系に反映された結 果であるといえる。

また改革によって, 教養科目群から修士課程で 5 単位 以上, 博士課程で 6 単位以上が修了要件に加わった。改 革以前は修士課程での 2 単位以上のみであったので, リーダーシップを備えた理工系人材の育成には教養科目 の重要性が認識された結果である。これも, 本学位プロ グラムを含む 4 つの博士課程教育リーディングプログラ ムの実績と経験に基づくものである。

教育改革による所属学生の負担増を最小限に抑える必 要があるが, それについては別稿で詳しく述べられる。

\section{IV. おわりに}

本学位プログラムは文部科学省の経済的支援で立ち上 がったが，この支援は平成 29 年度で終了する。平成 30 年度以降も本学位プログラムを継続し定着させる必要が ある。現在, どのように継続するかについて大学内で議 論されており，それについても別稿で詳しく述べられ る。

本学位プログラムを継続・定着させ，わが国のみなら ず世界の原子力界でグローバルリーダーとして活躍し貢 献する修了生を継続的に輩出することがわれわれの使命 であると考えている。

\section{一 参考資料 -}

1) http://www.jsps.go.jp/j-hakasekatei/index.html 本学位プ ログラムは, 平成 23 年度採択, オンリーワン型, F03 東京工 業大学.

2) 東京工業大学 - 大学院理工学研究科 . 原子核工学専攻, 全寮 制「グローバル原子力安全・セキュリティ・エージェント養 成」学位プログラムの構築による大学院教育改革と国際的 リーダー人材育成, 第 18 回工学教育賞 業績部門(公益社団 法人日本工学教育協会), 平成 26 年 8 月 28 日.

3) http://www.titech.ac.jp/education/

\section{著者紹介}

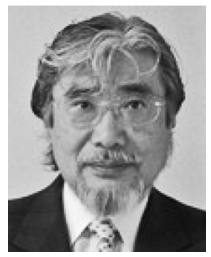
齊藤正樹（さいとう・まさき）

東京工業大学 グローバル原子力安全・セ キュリティ・エージェント教育院 (専門分野/関心分野) 原子炉安全, 核不拡 散，核セキュリティ 